\title{
Prevalence of multiple antibiotic resistance in Neisseria gonorrhoeae
}

\author{
D. J. PLATT \\ Department of Medical Microbiology, Charing Cross Hospital Medical School, London
}

\section{Summary}

The susceptibility of 100 strains of Neisseria gonorrhoeae to five antimicrobial agents (penicillin, streptomycin, oxytetracycline, sulphamethoxazole, and gentamicin) was examined. Three strains were resistant to each antimicrobial, fourteen exhibited resistance to three or four of the five compounds tested, and 49 were resistant to a single agent, or to pairs of the selected agents. 34 strains were found to be fully sensitive to all of the compounds tested.

It is suggested that resistance to gentamicin and sulphamethoxazole may be determined by a multiple resistance gene. The overall frequency of penicillin resistance was found to be 26.5 per cent (MIC> $0.06 \mu \mathrm{g} . / \mathrm{ml}$.), suggesting a significant decrease in resistance since 1968.

\section{Introduction}

Antibiotic resistance, and in particular resistance to penicillin, has become an increasing problem in the control of gonorrhoea (Curtis and Wilkinson, 1958; Wigfield, Selkon, and Rich, 1973; Stolz, Zwart, and Michel, 1975). Varying degrees of correlation of decreased susceptibility of Neisseria gonorrhoeae between pairs of antimicrobial agents have been observed (Reyn and Bentzon, 1968; Phillips, Rimmer, Ridley, Lynn, and Warren, 1970; Watko and Brownlow, 1975). Maness and Sparling (1973) have shown in vitro that multiple antibiotic resistance may be lost at low frequency in a single spontaneous step and that the selection of mutants, resistant to any o.ze antibiotic, restored multiple resistance, suggesting that multiple antibiotic resistance in gonococci is determined by a single gene.

However, the prevalence of multiple antibiotic resistant strains, in relation to strains exhibiting varying but lesser degrees of linked resistance, has

Received for publication March 18, 1976

Address for reprints: Mr D. J. Platt, Department of Microbiology, West London Hospital, Hammersmith, London W6 7DQ not been ascertained. The present study examined the susceptibility of strains of $N$. gonorrhoeae to five selected antimicrobials, and the frequency of related forms of resistance was determined.

\section{Material and methods}

One hundred consecutive isolates of $N$. gonorrhoeae were obtained from patients attending the Department of Genito-Urinary Medicine; there were 29 females and 71 males (21 homosexual and 50 heterosexual). Material obtained with a sterile plastic loop from urethra, cervix, or rectum, was directly inoculated on to a modified Thayer-Martin medium (Riddell and Buck, 1970) and incubated immediately for $48 \mathrm{hrs}$ at $37^{\circ} \mathrm{C}$. in candle extinction jars. $N$. gonorrhoeae was identified on culture, by oxidase reaction and microscopical appearance in Gram-stained films, and was confirmed by immunofluorescent staining (Beck, Fluker, and Platt, 1974).

$N$. gonorrhoeae was subcultured on Direct Sensitivity Agar (Oxoid) containing 10 per cent. lysed horse blood (DSTLB). Subcultures were harvested into 1 per cent. proteose peptone 3 ( 1 per cent. PP3) (Difco) containing 8 per cent. glycerol and $1 \mathrm{ml}$. aliquots were snap-frozen in liquid nitrogen (Ward and Watt, 1971). Ampoules containing gonococcal suspensions were thawed as required by immersion in waterbaths at $56^{\circ} \mathrm{C}$. for $2.5 \mathrm{~min}$. followed by $37^{\circ} \mathrm{C}$. for $20 \mathrm{~min}$.

DSTLB was also used for the routine maintenance of strains.

The minimum inhibitory concentration (MIC) was determined by the agar dilution method (Ericsson and Sherris, 1971). Serial dilutions of each antimicrobial agent were incorporated into DSTLB. The inoculum was prepared by suspending an overnight culture from DSTLB in $2 \mathrm{ml} .1$ per cent. PP3 and diluted to give faintly visible turbidity corresponding to $10^{7}-10^{8} \mathrm{cfu} / \mathrm{ml}$. The plates containing the antimicrobial agent were inoculated with $1 \mu l$. of each suspension using a multipoint inoculator (Denly Tech. Ltd.). They were incubated as for primary isolations. Staphylococcus aureus (Oxford strain) and two strains of $N$. gonorrhoeae (NCTC 8375 and NCTC 8448) were included as controls on each plate.

The antimicrobial agents selected were benzyl penicillin (Pen) (Glaxo), streptomycin sulphate (Str) (Glaxo), gentamicin (Gnt) (Nicholas), sulphamethoxazole (Smz) (Roche), and oxytetracycline (Tet) (Squibb). Stock 
solutions of penicillin, streptomycin, and gentamicin were prepared in distilled water, sulphamethoxazole in $0 \cdot 1$ $M$ sodium hydroxide, and oxytetracycline in $0.1 \mathrm{M}$ hydrochloric acid. The MICs above which any strain was considered to be resistant were penicillin $0.06 \mu \mathrm{g} . / \mathrm{ml}$., streptomycin $25 \mu \mathrm{g} . / \mathrm{ml}$., gentamycin $0.78 \mu \mathrm{g} . / \mathrm{ml}$., sulphamethoxazole $16.0 \mu \mathrm{g} . / \mathrm{ml}$, , and oxytetracycline $0.78 \mu \mathrm{g} . / \mathrm{ml}$.

\section{Results}

The distribution of MICs of the selected antimicrobial agents for $N$. gonorrhoeae is shown in Table I. Penicillin and streptomycin clearly show a bimodal distribution, while gentamicin, sulphamethoxazole, and oxytetracycline do not resolve into distinct peaks. Penicillin resistance $(\mathrm{MIC}>0.06$ $\mu \mathrm{g} . / \mathrm{ml}$.) was found in 26.5 per cent. of the strains. Table II shows the correlation coefficient $(r)$ for the MICs of paired antimicrobial agents. The value of $r$ was found to be $>0.5$ for Pen/Str, Pen/Tet, and Str/Tet, and $>0.2$ for Pen/Gnt, Pen/Smz, and Tet/Smz. No significant correlation was found between Str/Gnt, Str/Smz, Gnt/Smz, and Tet/Gnt.

TABLE II Correlation coefficients ( $\mathbf{r}$ ) of MICs for paired antimicrobial agents

\begin{tabular}{lllll}
\hline Str & $0.556^{\mathrm{a}}$ & & & \\
\hline Tet & $0.616^{\mathrm{a}}$ & $0.627^{\mathrm{a}}$ & & \\
\hline Smz & $0.216^{\mathrm{a}}$ & 0.079 & $0.232^{\mathrm{a}}$ & \\
\hline Gnt & $0.215^{\mathrm{a}}$ & 0.013 & 0.141 & 0.086 \\
\hline & Pen & Str & Tet & Smz \\
\hline
\end{tabular}

aindicates significant correlation $(P<0.05)$.

Of the 100 strains examined, three were found to be resistant to each of the antimicrobials examined, having MICs of penicillin at $1.0 \mu \mathrm{g} . / \mathrm{ml}$. (2 strains) and $0 \cdot 12 \mu \mathrm{g} . / \mathrm{ml}$. (1 strain) and of tetracycline at $3 \cdot 1 \mu \mathrm{g} . / \mathrm{ml}$. (3 strains). Fourteen strains showed resistance to three or four of the five antimicrobials. A further fourteen strains were resistant to two of the five compounds and 35 were resistant to single antimicrobials. Of these 35 strains, 25 were resistant to either sulphamethoxazole or gentamicin. 34 strains were sensitive to each of the antimicrobials tested (Table III). No significant difference was observed in the frequency of isolation of resistant strains from homosexual and heterosexual patients $\left(\chi_{1}^{2}\right.$ test; $\mathrm{P}<0.05)$.

TABLE II I Number of strains of N. gonorrhoeae exhibiting resistance to the five antimicrobials, singly and in combination (/).

\begin{tabular}{|c|c|c|c|}
\hline \multicolumn{2}{|c|}{$\begin{array}{l}\text { No. and name of antimicrobials to which } \\
\text { resistance was observed }\end{array}$} & \multirow{2}{*}{$\begin{array}{l}\text { No. of strains } \\
\text { exhibiting } \\
\text { resistance } \\
3\end{array}$} & \multirow{2}{*}{$\begin{array}{l}\text { Total } \\
3\end{array}$} \\
\hline 5 & Pen/Str/Tet/Smz/Gnt & & \\
\hline 4 & $\begin{array}{l}\text { Pen/Str/Tet/Smz } \\
\text { Pen/Str/Tet/Gnt }\end{array}$ & $\begin{array}{l}4 \\
4\end{array}$ & 8 \\
\hline 3 & $\begin{array}{l}\text { Pen/Str/Tet } \\
\text { Pen/Smz/Tet } \\
\text { Str/Smz/Tet }\end{array}$ & $\begin{array}{l}4 \\
1 \\
1\end{array}$ & 6 \\
\hline 2 & $\begin{array}{l}\text { Pen/Str } \\
\text { Gnt/Smz } \\
\text { Tet/Gnt } \\
\text { Tet/Str } \\
\text { Pen/Tet } \\
\text { Tet/Smz }\end{array}$ & $\begin{array}{l}4 \\
4 \\
2 \\
2 \\
1 \\
1\end{array}$ & 14 \\
\hline 1 & $\begin{array}{l}\text { Gnt } \\
\text { Smz } \\
\text { Tet } \\
\text { Str } \\
\text { Pen }\end{array}$ & $\begin{array}{r}14 \\
11 \\
4 \\
3 \\
3\end{array}$ & 35 \\
\hline 0 & - & 34 & 34 \\
\hline
\end{tabular}

MICs above which any strain was considered to be resistant were:

Pen $>0.06 \mu \mathrm{g} . / \mathrm{ml}$.; Str $>25.0 \mu \mathrm{g} . / \mathrm{ml}$.; Tet $>0.78 \mu \mathrm{g} . / \mathrm{ml}$;

$\mathrm{Smz}>16.0 \mu \mathrm{g} . / \mathrm{ml}$; Gnt $>0.78 \mu \mathrm{g} . / \mathrm{ml}$.

\section{Discussion}

The wide variety of antibiotic resistance patterns observed illustrates the polygenic nature of resistance in N. gonorrhoeae (Maier, Zubrzycki, and Coyle, 1975a; Maier. Zubrzycki, Coyle, Chila, and Warner, 1975b).

TABLE I Frequency distributions of minimum inhibitory concentrations of five antimicrobial agents for N. gonorrhoeae

\begin{tabular}{|c|c|c|c|c|c|c|c|c|c|}
\hline \multirow{2}{*}{$\frac{\text { Antimicrobial agent }}{\text { Penicillin }}$} & \multicolumn{8}{|c|}{ No. of strains with MICs $(\mu \mathrm{g} . / \mathrm{ml}$.) in bold type } & \multirow{2}{*}{$\begin{array}{l}\begin{array}{l}\text { Total no. of } \\
\text { strains }\end{array} \\
95\end{array}$} \\
\hline & $\begin{array}{l}0 \cdot 007 \\
54\end{array}$ & $\begin{array}{l}0 \cdot 015 \\
7\end{array}$ & $\begin{array}{l}0.03 \\
2\end{array}$ & $\begin{array}{l}0 \cdot 06 \\
7\end{array}$ & ${ }_{13}^{0 \cdot 12}$ & $\begin{array}{l}0 \cdot 25 \\
6\end{array}$ & $\begin{array}{l}0 \cdot 50 \\
4\end{array}$ & $2^{1 \cdot 0}$ & \\
\hline Streptomycin & $1^{1 \cdot 56}$ & $2^{3 \cdot 12}$ & $37^{\mathbf{6} \cdot 25}$ & $\begin{array}{c}12 \cdot 5 \\
3\end{array}$ & $\begin{array}{c}\mathbf{2 5} \cdot \mathbf{0} \\
0\end{array}$ & $\begin{array}{c}50 \cdot 0 \\
0\end{array}$ & & $\begin{array}{c}>\mathbf{5 0} \cdot 0 \\
24\end{array}$ & 95 \\
\hline Gentamicin & $\begin{array}{l}0 \cdot 09 \\
6\end{array}$ & $\begin{array}{l}0 \cdot 19 \\
4\end{array}$ & 26 & ${ }_{29}^{0 \cdot 78}$ & $23^{1 \cdot 56}$ & $\begin{array}{l}3 \cdot 12 \\
4\end{array}$ & & $\begin{array}{l}\mathbf{6} \cdot \mathbf{2 6} \\
0\end{array}$ & 92 \\
\hline Sulphamethoxazole & $\begin{array}{l}1 \cdot 0 \\
2\end{array}$ & $\begin{array}{l}2 \cdot 0 \\
2\end{array}$ & $22^{4 \cdot 0}$ & $\begin{array}{l}8 \cdot 0 \\
18\end{array}$ & $\begin{array}{l}16 \cdot 0 \\
25\end{array}$ & $\begin{array}{l}32 \cdot 0 \\
14\end{array}$ & & $\begin{array}{l}64 \cdot 0 \\
12\end{array}$ & 95 \\
\hline Oxytetracycline & $\begin{array}{l}0 \cdot 09 \\
5\end{array}$ & $\begin{array}{l}0 \cdot 19 \\
11\end{array}$ & $\begin{array}{l}0 \cdot 39 \\
14\end{array}$ & $\begin{array}{l}0 \cdot 78 \\
31\end{array}$ & $11^{1 \cdot 56}$ & $15^{3 \cdot 12}$ & & $\begin{aligned} & 3 \cdot 12 \\
& 1\end{aligned}$ & 88 \\
\hline
\end{tabular}


The MICs of penicillin and tetracycline in the three strains resistant to each of the compounds examined confirms the observation of Maness and Sparling (1973) that the highest levels of resistance to penicillin and tetracycline were found in strains exhibiting multiple resistance. Multiple antibiotic resistance genes (ery, $m$ tr) have been shown to confer only low level resistance while the higher resistance levels observed result from the interaction of two or more distinct gene loci, and thus isolates resistant to multiple drugs, including penicillin and tetracycline, at the higher resistance levels are the product of multiple rather than single mutations. However single mutation in a gene designated $e n v$ is able to restore multiple resistance in phenotypically sensitive strains, since the action of this gene results in phenotypic suppression of resistance determinants (Sparling, Sarubbi, and Blackman, 1975; Sarubbi, Sparling, Blackman, and Lewis, 1975). Thus the three most resistant strains described represent multiple mutants containing an ery-like gene which may regulate the expression of both sulphamethoxazole and gentamicin resistance.

The positive correlations for pairs of antimicrobials observed (Table II) are less marked than those found by either Maness and Sparling (1973) or Phillips and others (1970). This could be explained by the presence of vancomycin in the initial isolation medium, since Brorson, Holmberg, Nygren, and Seeberg (1973) found about 10 per cent. of gonococcal strains to be sensitive to $3 \mu \mathrm{g}$. $/ \mathrm{ml}$. vancomycin; furthermore, vancomycin-sensitive strains are more sensitive to other antimicrobials (Reyn, 1969). Thus a proportion of the sensitive strains would be removed and the correlation coefficients decrease accordingly. The distribution of MICs of tetracycline is similar to that found by Ronald, Eby, and Sherris (1968) and Maier, Beilstein, and Zubrzycki (1974). Resistance to sulphamethoxazole appears to be of higher frequency than has been recently reported (Lawrence, Phillips, and Nicol, 1973; Stolz and others, 1975). Although the MIC distributions closely parallel those obtained by Phillips and others (1970) for penicillin, streptomycin, and gentamicin, in the present study 26.5 per cent. of strains were found to be partially resistant to penicillin (MIC $>0.06 \mu \mathrm{g} . / \mathrm{ml}$.) compared to 35.5 per cent. (Phillips and others, 1970) and $37 \cdot 3$ per cent. (Nicol, Ridley, and Symonds, 1968). This appears to be a significant decrease $\left(\chi_{1}^{2}\right.$ test; $\left.P<0.05\right)$ in the frequency of penicillin resistance over 7 years in a geographically similar patient population, using the same level of resistance demarcation. That this decrease represents differences in the techniques employed cannot be excluded.

I thank Dr J. L. Fluker for his cooperation in the collection of strains and Professor H. I. Winner, Doctors A. Gerken, and D. J. M. Wright for their advice. I am grateful to the Clinical Research Committee of the Charing Cross Hospital for their support.

\section{References}

Beck, A., Fluker, J. L., and Platt, D. J. (1974) Brit. f. vener. Dis., 50, 367

Brorson, J. E., Holmberg, I., Nygren, B., and SeEberg, S. (1973) Ibid., 49, 452

CurTIS, F. R., and WiLkINson, A. E. (1958) Ibid., 34, 70

ERICsSON, H. M., and SHERRIS, J. C. (1971) Acta path. microbiol. scand., 79B, Suppl. 217

Lawrence, A., Phillips, I., and Nicol, C. (1973) $\mathcal{f}$. infect. Dis., 128, Suppl. p.673

MAIER, T. W., BEILSTEIN, H. R., and ZUBRZYCKI, L. (1974) Antimicrob. Agents Chemother., 5, 210

-, ZuBrzycki, L., and Coyle, M. B. (1975a) Ibid., 7,676

$-\longrightarrow,-$, CHILA, M., and WARNER, P. (1975b) f. Bact., 124, 834

Maness, M., and Sparling, P. F. (1973) $\mathcal{f}$. infect. Dis., 128,321

Nicol, C. S., Ridley, M., and Symonds, M. A. E. (1968) Brit. F. vener. Dis., 44, 315

Phillips, I., Rimmer, D., Ridley, M., LynN, R., and WARREN, C. (1970) Lancet, 1, 263

ReYN, A. (1969) Bull. Wld Hlth Org., 40, 245

and Bentzon, M. W. (1968) Brit. F. vener. Dis., 44, 140

RidDell, R. H., and BuCK, A. C. (1970) f. clin. Path., 23, 481

Ronald, A. R., Eby, J., and Sherris, J. C. (1968) Antimicrob. Agents Chemother., p. 431

Sarubbi, F. A., Sparling, P. F., Blackman, E., and LEwIS, E. (1975) F. Bact., 124, 750

Sparling, P. F., Sarubbi, F. A., and Blackman, E. (1975) Ibid., 124, 740

Stolz, E., Zwart, H. G. F., and Michel, M. F. (1975) Brit. F. vener. Dis., 51, 257

WARD, M. E., and WATT, P. J. (1971) f. clin. Path., 24, 122

WATKo, L. P., and Brownlow, W. J. (1975) Brit. F. vener. Dis., 51, 34

Wigfield, A. S., Selkon, J. B., and Rich, G. E. (1973) Ibid., 49, 277 